\title{
Why the Quality Of Refill Drinking Water Depots Is Bad (As a Qualitative Study)
}

\author{
Azyyati Ridha Alfian*, Fea Firdani, Putri Nilam Sari \\ Fakultas Kesehatan Masyarakat, Universitas Andalas, Jl. Perintis Kemerdekaan No.94, Padang, Sumatera Barat 25171, \\ Indonesia. \\ *Corresponding author: azyyatiridhaalfian@ph.unand.ac.id
}

Info Artikel:Diterima 12 Januari 2022 ; Direvisi 7 Februari 2022 ; Disetujui 17 Februari 2022

Tersedia online : 19 Februari 2022 ; Diterbitkan secara teratur : Februari 2022

Cara sitasi (Vancouver): Alfian AR, Firdani F, Sari PN. Why the Quality Of Refill Drinking Water Depots Is Bad (As a Qualitative Study). Jurnal Kesehatan Lingkungan Indonesia [Online]. 2022 Feb;21(1):106-110. https://doi.org/10.14710/jkli.21.1.106-110.

\begin{abstract}
ABSTRAK
Latar belakang: Data Dinas Kesehatan Kota Pariaman berdasarkan uji laboratorium terhadap kualitas air minum dari Depot Air Minum Isi Ulang menunjukkan bahwa setiap tahun lebih dari 50\% air minum tidak memenuhi syarat untuk air minum. Penelitian ini bertujuan untuk menganalisis faktor penyebab buruknya kualitas Depot Air Minum Isi Ulang di Kota Pariaman, Sumatera Barat, Indonesia.

Metode: Penelitian ini bersifat kualitatif dengan pendekatan fenomenologi yang dilaksanakan di beberapa Depot Air Minum Isi Ulang, Dinas Kesehatan, dan beberapa Puskesmas di Kota Pariaman pada bulan FebruariJuni 2021. Informan berjumlah 9 orang. Data diperoleh dengan melakukan wawancara mendalam dengan 9 informan. Analisis data menggunakan transkripsi, reduksi, koding, kategorisasi, penyajian data dan interpretasi data faktor penyebab buruknya kualitas DAMIU di kota Pariaman

Hasil: Rendahnya kualitas air minum isi ulang di Kota Pariaman disebabkan oleh rendahnya pengetahuan pemilik atau pekerja mengenai higiene sanitasi di depot air minum isi ulang yang berdampak pada buruknya praktik higiene sanitasi dalam menjaga kualitas air minum. Hal ini juga sejalan dengan kurangnya sosialisasi dan edukasi dari Dinas Kesehatan setempat dan pihak terkait mengenai higiene dan sanitasi.

Simpulan: Karena minimnya pengetahuan dan buruknya praktik higiene sanitasi oleh petugas Depot Air Minum Isi Ulang, maka Dinas Kesehatan harus selalu melakukan sosialisasi dan edukasi secara intensif dan berkesinambungan untuk meningkatkan kualitas air minum isi ulang kepada setiap operator Depot Air Minum Isi Ulang.
\end{abstract}

Kata kunci: Air Minum; Depot Air Minum Isi Ulang; Higiene Sanitasi; Kualitas Air Minum

\footnotetext{
ABSTRACT

Background: Data from Health Office of Pariaman City mentioned that based on laboratory tests on the quality of drinking water from Refill Drinking Water Depots showed that every year more than 50\% does not meet requirements for drinking water. This study aimed to analyze factors of the bad quality of drinking Refill Drinking Water Depots Quality in Pariaman City, Indonesia.

Method: This research is qualitative with a phenomenological approach which was carried out in several Refill Drinking Water Depots, Health Office, and several Public Health Center in Pariaman City in February-June 2021. There were 9 informants. Data were obtained by conducting in-depth interviews with 9 informants. Data were analyzed using transcription, reduction, coding, and categorization of data presentation and data interpretation about factors of the bad quality of drinking Refill Drinking Water Depots Quality in Pariaman City.
} 
Result: The low quality of refill drinking water in Pariaman City is caused by the low knowledge of the owners or workers regarding the sanitation hygiene of the refill drinking water in depots which has an impact on poor sanitation hygiene practices in maintaining drinking water quality. This is also in line with the lack of socialization and dissemination of information from the local Health Office and related parties regarding hygiene and sanitation.

Conclusion: Since the lack of knowledge and poor sanitation hygiene practices by Refill Drinking Water Depot officers, the Health Office should always provide intensive and sustainable socialization and information dissemination to improve the quality of refill drinking water to every operator of Refill Drinking Water Depots

\section{Keywords: Drinking Water; Drinking Water Quality; Hygiene Sanitation; Refill Drinking Water Depot}

\section{INTRODUCTION}

Water is one of the most vital needs for human life. Human needs for water are very complex, such as for cooking, drinking, washing, and so on. The most important thing of water utilization for humans is for drinking needs. The human body consists mostly of water which is about $60-70 \%$ of its body weight which is useful for helping the digestive process, regulating metabolism, transporting food substances in the body, regulating body temperature balance, and keeping the body from drying out. ${ }^{1,2}$

Purified or unpurified water that fulfills health standards and may be drunk directly is referred to as drinking water. The government sets strict standards for what constitutes safe drinking water. Drinking water is safe for health if it passes physical, chemical, and bacteriological standards, which include the absence of Escherichia coli bacteria and other Coliform bacteria. Water that does not satisfy bacteriological standards contributes $88 \%$ to global child fatalities from diarrhea, according to the World Health Organization. ${ }^{3,4}$

Clean drinking water is water that has passed the feasibility test according to applicable regulations. The supply itself can be sourced from various types. Starting from water provided by the drinking water service, bottled water, and what has recently emerged and become a cheaper alternative to drinking water is refilled drinking water. ${ }^{5}$ In the present state of civilization, as human activity increases, so does the need for drinking water, which leads to an increase in the number of water supply facilities. There are other alternatives to bottled water, like Refill Drinking Water Depot's tap water, which is popular in cities and has even spread to rural regions because of its low cost compared to other options. Beginning in 1999, Indonesia's Refilling Water Depots appeared. Drinking water is produced and sold directly to consumers by Refill Drinking Water Depot, a manufacturing company. ${ }^{6,7,8}$

Based on data from the Indonesia Health Profile (2019), the number of refill drinking water depots in Indonesia is 51,971 depots, but only $20,532(39.51 \%)$ depots meet the requirements. ${ }^{9}$ This is in line with the conditions in West Sumatra where out of 2009 depots, only $980(48.78 \%)$ drinking water depots have met the requirements. According to the results of drinking water sample analysis conducted in 10 major
Indonesian cities (Jakarta, Tangerang, Bekasi, Bogor, Cikampek, Medan, Denpasar, Yogyakarta, Semarang, and Surabaya), $34 \%$ of the samples did not meet at least one drinking water quality parameter, and $16 \%$ of the samples were contaminated with coliform bacteria. $^{8}$

Data for Basic Health Research (Riskesdas) of West Sumatra Province (2013) showed 46.4\% of households prefer to use refilled drinking water originating from refill drinking water depots as a source of drinking water. The data also showed that Pariaman City is one of the highest cities that use refilled drinking water sources from refill drinking water depots, which is $56.1 \%$. The number of drinking water depots in Pariaman City from 2016-2020 is known continue to increase every year. In 2016 there were 58 refill drinking water depots and increase with 78 refill drinking water depots until 2020. This increase continues every year throughout 2016-2020. This is based on the fact that people start to think that refill drinking water depot is one of the most profitable industrial enterprises. ${ }^{10}$

Based on data from the Office of One Stop Investment and Integrated Services and Manpower Office of Pariaman City, the are 78 refill drinking water depots, but only 11 refill drinking water depots that have a drinking water depot business license. Pariaman City Health Office (2020) data shows that more over half of the drinking water from replenish drinking water depots in Pariaman City does not fulfill health and drinking-water standards every year, based on laboratory testing of the quality of the water. Refill water depot drinking water quality continues to improve from 2016 to 2020, as seen in the following graphs. ${ }^{11}$ The quality of replenishment water depots in Pariaman City will continue to deteriorate from 2016 to 2020 . By $2020,65 \%$ of refill drinking water depots would have failed to comply with the regulations. ${ }^{12}$

According to the previous statistics, the quality of drinking water generated by refill drinking water depots is typically troublesome since it does not match the drinking water quality criteria. Each refill drinking water depot has inadequate sanitary cleanliness, which is one of the reasons. Anecdotal evidence suggests that about half of the refill drinking water depots in District Ligung, Majalengka, do not fulfill the required microbiological quality standards for the presence of Coliform and E. coli. The 
microbiological purity of refilled drinking water is affected by sanitary hygiene, namely the use of adequate and proper equipment. ${ }^{13}$ Efforts to prevent contamination of drinking water facilities are made via sanitation hygiene. Humans should be shielded from the harmful effects of water refill stations. The results of this study were also strengthened, he claimed that in East Jakarta also showed the low bacteriological quality of refill drinking water due to low knowledge, attitudes, hygiene behavior, and lack of awareness and training on hygiene by the manager of refill drinking water depots. ${ }^{14}$

The Pariaman City Government's policy in realizing the provision of safe drinking water for the community is to issue Regional Regulation Number 9 of 2015 which contains a Drinking Water Depot Business License. The Regional Regulation Number 9 of 2015 has regulated everything from drinking water quality requirements, supervision management, funding and sanctions for violations committed, but the expected results have not been maximized by looking at the high quality of drinking water that does not meet health requirements from the refill drinking water depots. ${ }^{11}$

Pariaman City has seen a rise in the number of refill drinking water depots in recent years, however despite this, the quality of water generated by these depots still falls short of the standards required, and many of these depots still lack a business license. As a result, the authors' research focuses on the internal and external variables that contribute to the poor quality of drinking water from Pariaman City's replenish drinking water depots.

\section{MATERIAL AND METHOD}

Research conducted in this study is qualitative and uses a phenomenological perspective. Research using the qualitative technique collects data in the form of descriptions provided by participants or by observing their actions and verbal descriptions provided by the participants. ${ }^{15}$. While the phenomenological approach aims to describe the meaning of an individual's life experience or the concept of a particular phenomenon. The research was carried out at several Refill Drinking Water Depots in Pariaman City, Health Office of Pariaman City, and several Public Health Center in Pariaman City, Indonesia which were held in February-June 2021. The Refill Drinking Water Depots and the selected Public Health Center represented each subdistrict in Pariaman City. Four officers/owners of the Refill Drinking Water Depots, four sanitarians from the Public Health Center, and a license holder from the Pariaman City Health Office were the nine persons that participated in this study..

Selected informants are those in charge of running the replenishment drinking water depot and monitoring its execution in terms of quality and cleanliness. Informants were interviewed in-depth to gather data. Pariaman City's refill water depots have poor sanitation and hygiene procedures, as well as an inadequate monitoring method, according to the data gathered and reviewed by the researchers. Transcription, reduction, coding, and classification of data presentation and interpretation were used in the data analysis process.

\section{RESULT AND DISCUSSION}

The results of in-depth interviews described that the knowledge of the owners or workers of the Refill Drinking Water Depots is still low regarding sanitation and hygiene that they need to pay attention to. It is proved by the answers of respondents who stated that they did not know how to keep the environment clean at the depot location, how to treat drinking water properly and correctly, how to manage and care for the equipment used, and the importance of maintaining the health and hygiene of depot workers. The low knowledge of workers about sanitation hygiene has an impact on poor sanitation hygiene practices. Refill drinking water is at danger of contamination due to insufficient sanitary hygiene measures. When a water depot's owner lacks understanding, they are less attentive and compliant in preserving water quality since they don't take proper care of the equipment. In addition, the refill drinking water depot workers do not apply clean living behaviors in their work, such as washing their hands before refilling water, not smoking and wearing clean clothes.

These unclean behaviors can be the cause of microbial contamination that enable refill drinking water to be contaminated during the process. Hand washing is a way to avoid microbial contamination or contamination of tools and materials. Personal hygiene is an important factor influencing the spread of 2 microbes in foods and drinks. ${ }^{16,17,18}$

Operator hygiene is a problem that often goes unnoticed at the refill drinking water depot. E.Coli was found in refilled drinking water in District Bungus, Padang, due to the operator's lack of awareness about hygiene and sanitation at the refill drinking water depot, according to a study. ${ }^{19}$ It was also found that operator cleanliness and the quality of replenished drinking water in Demak were linked, according to Demak-based study. Operator participation in seminars and training on sanitation hygiene is important to note since it will increase operator knowledge that will enable the implementation of clean-living behavior by operators of refill drinking water depots. ${ }^{20,21}$

There are additional factors that contribute to the poor quality of refilled drinking water, such as an inadequate monitoring procedure. The Health Office of Pariaman City, which is represented by the local Public Health Center, supervises the refilling of drinking water. Coaching, counseling, regular inspections, and the selection of examinations are some of the tasks that are carried out as part of supervision. However, in practice, the Health Office 
and Public Health Center only carry out inspections of drinking water samples and are not accompanied by sanitation inspections, socialization, and conducting training for owners or workers of refill drinking water depots.

As a result, the government's execution of oversight has not yet been optimized. The owners and employees of the refill drinking water depot have little understanding of the sanitary hygiene of the depot itself because of a lack of socialization of the owners and personnel. There was also a delay in socializing activities since there were not enough sanitarians working in the field and they had a lot of extra work to complete.

Supervision involves setting goals and monitoring progress toward them, as well as taking steps to ensure that the desired outcomes are met. To put it another way, the supervisory role is the establishing of performance criteria and the activities that must be taken to meet those requirements. ${ }^{22,23}$

In an ideal world, more refill drinking water depots would make high-quality water more readily available to more people. This has not been accomplished in practice, however, due to the large number of refilled drinking water depots that do not fulfill the minimum standards. Some research results that mention the number of drinking water depots which produces drinking water that is not following health requirements showed a weak supervision function of the operation of drinking water depots. This problem must be addressed immediately and seriously through a good supervisory function by owners of refill drinking water depot, government, and citizen, considering that drinking water is vital for human life. ${ }^{24,25}$

Apart from being the responsibility of the manager or owner of the refill drinking water depot, operators of supervision and hygiene development also requires support and cooperation from the government and the local health office. One of the collaborations that can be carried out by the government and the health department to change unsanitary living behavior on operators is to facilitate seminars or training related to sanitation hygiene to owners, managers, and operators of refill drinking water depots which are expected to increase knowledge and application of clean- living behavior on operators of refill drinking water depots. ${ }^{26,27}$

\section{CONCLUSIONS}

The inadequate sanitation hygiene knowledge and poor sanitation hygiene behavior of owners and personnel of refill drinking water depots in Pariaman City contribute to the poor quality of the city's refill drinking water. A lack of socialization and training on the necessity of preserving drinking water quality to owners and staff at refill depots has hindered effective oversight by the appropriate authorities.

\section{ACKNOWLEDGEMENT}

The authors would like to thank related parties who have helped so that the implementation of this research can run smoothly, including the research team, leaders, colleagues, Owner/Supervisor of Pariaman City Refill Drinking Water Depot, Pariaman City Health Office, Pariaman Health Center, Sanitarian Health Center and all respondents who have been willing to take the time to provide related information. With all humility, hopefully the results of this research can be useful and useful for all parties.

\section{BIBLIOGRAPHY}

1. Asmadi, Khayan, K.H. Teknologi Pengolahan Air Minum. Yogyakarta, Indonesia; 2011.

2. Notoadmodjo, S. Ilmu Kesehatan Masyarakat: Prinsip - Prinsip Dasar. Rineka Cipta, Jakarta; 2020

3. Peraturan Menteri Kesehatan Republik Indonesia. Nomor 492 tentang Persyaratan Kualitas Air Minum. Jakarta; 2014.

4. Unicef Indonesia. Ringkasan Kajian Air Bersih Sanitasi Dan Kebersihan. Unicef Indonesia, Jakarta; 2012

5. Purba, Ig. Supervision Of Implementation Of Drinking Water Depot In Ensuring Quality Of Refill Drinking Water, Jurnal Ilmiah Kesehatan Masyarakat 2015, 6(2).

6. Keputusan Menteri Perindustrian dan Perdagangan Republik Indonesia. Nomor 651. Persyaratan Teknis Depot Air Minum Dan Perdagangan. Jakarta; 2004

7. Keman, S. Quality Of Refilled Drinking Water In Surabaya. Folia Medica Indonesiana 2005, 41(1)

8. Putri, S., Nastiti, A., Muntalif, B.S. Applying Quantitative Microbial Risk Assesment In Household Drinking Water Sources: A Case Study Of Ujung Berung Subdistric Bandung. The 5th Environmental Technology And Management Conference Green Technology Towards Sustainable Environment, Bandung; 2015.

9. Departemen Kesehatan RI. Profil Kesehatan Indonesia Tahun 2019. Jakarta; 2020

10. Kementerian Kesehatan RI. Riset Kesehatan Dasar. Badan Penelitian dan Pengembangan. Jakarta; 2013

11. Walikota Pariaman. Peraturan Daerah Nomor 9 Tahun 2015 tentang Izin Usaha Depot Air Minum. Pariaman; 2015.

12. DKK Pariaman. Laporan Seksi Kesehatan Lingkungan. Kesehatan Kerja dan Olahraga. Pariaman; 2015.

13. Iman, N.T., and Lucky, H. Analisis Laik Sehat Dan Kualitas Mikrobiologis Air Minum Isi Ulang Di Kecamatan Ligung, Majalengka. 
2016,32:179-182.

https://doi.org/10.22146/bkm.7606

14. Malik, R. Hubungan Pengetahuan, Sikap Dan Perilaku Higiene Pengelola Depot Air Minum Isi Ulang Dengan Kualitas Bakteriologis Air Minum Isi Ulang Di Jakarta Timur Dengan Metode Most Probable Number (MPN). Thesis. Universitas Pembangunan Nasional Veteran Jakarta. Jakarta; 2016.

15. HR, Hasdianah. Panduan Laboratorium Mikrobiologi Dan Rumah Sakit. Nuha Medika, Yogyakarta; 2011.

16. Irianto, K. Mikrobiologi Menguak Dunia Mikroorganisme. Jilid 2. CV.Yrama Widya, Bandung; 2007.

17. Kiantoa, A., Sáenzb, J., Aramburub, N. Knowledge- Based Human Resource Management Practices. Intellectual Capital And Innovation. J Business Res 2017, 81:11- 20. https://doi.org/10.1016/j.jbusres.2017.07.018

18. Wandrivel, R., Netty, S., Yuniar, L. Kualitas Air Minum Yang Diproduksi Depot Air Minum Isi Ulang Di Kecamatan Bungus Padang Berdasarkan Persyaratan Mikrobiologi. Jurnal Kesehatan Andalas, Padang 2012, 1(3): 129-33. https://doi.org/10.25077/jka.v1i3.84

19. Mirza, N.M. Hubungan Antara Higiene Sanitasi Dengan Jumlah Coliform Air Minum Pada Depot Air Minum Isi Ulang (Depot Air Minum Isi Ulang) Di Kabupaten Demak Tahun 2012. UJPH, 3(2).

20. Sima, L.,C., Desai, M.M., McCarty, K.M., Elimelech,M. Relationship Between Use Of Water From Community- Scale Water Treatment Refill Kiosks And Childhood Diarrhea In Jakarta. Am J Trop Med Hyg 2012, 87(6): $\quad 979-\quad 84$. https://doi.org/10.4269/ajtmh.2012.12-0224
21. Sule, E.T., Saefullah, K. Pengantar Manajemen.Edisi Pertama. Prenada Media, Jakarta; 2005

22. Simanjuntak, S. and Mikael, M. Pengawasan Terhadap Depor Air Minum Isi Ulang, Fokus 2019, 17(1),105120.https://doi.org/10.51826/fokus.v17i1.273

23. Puspitasari, E. Analysis Of The Factors Affecting The Quality Of The Chemical And Microbiological Drinking Water At The Depot Drinking Water Refill Tulungagung District. Journal For Quality In Public Health 2018, 1(1). https://doi.org/10.30994/jqph.v1i1.10

24. Ardini, R., Yusnita, I.S., Deni, K. Water Quality From Drinking Water Sources Of Slum Dwellers In Developing Country; Case Of Urban Slum Area In Cikapundung River Basin Bandung, Indonesia. Proceeding The 3rd International Seminar on Environtmental Health Faculty of Public Health, Airlangga University, Surabaya; 2015

25. Gebauer, H., Saul ,CJ. Bussiness Model Intervention In The Water Sector In Developing Countries, Sci Total Environ 2014, 488-9, 51220.

https://doi.org/10.1016/j.scitotenv.2014.02.046 26. Cope, M.A.B., Gutierrez, S.A.S., Mañalac, M.M.C., Ocampo, M.L.A., Pauline, P., Perez, P.P., Quizon, R.R. Knowledge and Practices of Water Refilling Station Owners and Operators in Providing Safe and Wholesome Drinking Water Supply in One Municipality of Cavite, Acta Medica Philiphina 2013, 47: 22-30. https://doi.org/10.47895/amp.v47i2.1360 